\title{
CD10 is expressed in a subset of chromophobe renal cell carcinomas
}

\author{
Guido Martignoni ${ }^{1}$, Maurizio Pea ${ }^{2}$, Matteo Brunelli², Marco Chilosi², Alberto Zamó², \\ Manuela Bertaso ${ }^{2}$, Paolo Cossu-Rocca ${ }^{1}$, John N Eble ${ }^{3}$, Gregor Mikuz ${ }^{4}$, Giacomo Puppa ${ }^{5}$, \\ Cecile Badoual ${ }^{6}$, Vincenzo Ficarra ${ }^{7}$, Giovanni Novella ${ }^{7}$ and Franco Bonetti ${ }^{2}$ \\ ${ }^{1}$ Anatomia Patologica, Università di Sassari, Sassari, Italy; ${ }^{2}$ Anatomia Patologica, Università di Verona, \\ Verona, Italy; ${ }^{3}$ Department of Pathology and Laboratory Medicine, Indiana University, Indianapolis, IN, USA; \\ ${ }^{4}$ Department of Pathology and Laboratory Medicine, Innsbruck University, Austria; ${ }^{5}$ Department of Pathology \\ and Laboratory Medicine, Istituto Europeo di Oncologia, Milano, Italy; ${ }^{6}$ Department of Pathology and \\ Laboratory Medicine, Hôpital Européen George Pompidou, Paris, France and ${ }^{7}$ Dipartimento di Urologia, \\ Università di Verona, Verona, Italy
}

\begin{abstract}
CD10 has been considered a useful marker in the diagnosis of renal carcinomas, because of its expression in clear cell and papillary renal cell carcinomas and its absence in chromophobe renal cell carcinomas. On the other hand, chromophobe renal cell carcinoma expresses parvalbumin, which is absent in clear cell and papillary renal cell carcinomas. To further address the relevance of these markers, we studied the expression of CD10 and parvalbumin in $\mathbf{4 2}$ samples of chromophobe renal cell carcinoma (seven of which had aggressive features, including invasion beyond the renal capsule, renal vein invasion, metastases, or sarcomatoid transformation), 75 clear cell renal cell carcinomas (eight metastatic) and 51 papillary renal cell carcinomas (two metastatic). CD10 was found in $100 \%$ of clear cell renal cell carcinomas, $63 \%$ of papillary renal cell carcinomas and in all metastatic cases of both types. At variance with previous studies, we found CD10 expression in from 30 to $90 \%$ of the neoplastic cells, in 11 of $42(26 \%)$ chromophobe renal cell carcinomas. The CD10-positive cases included five of the seven $(71 \%)$ chromophobe renal cell carcinoma with aggressive features. Statistical analysis showed significant association of CD10-positive tumors with clinicopathologic aggressiveness $(P=0.003)$ and mitotic figures $(P=0.04)$. Parvalbumin was strongly expressed in all primary and metastatic chromophobe renal cell carcinomas. Western blot analysis was utilized to confirm the expression of both CD10 and parvalbumin in chromophobe renal cell carcinomas.
\end{abstract}

Modern Pathology (2004) 17, 1455-1463, advance online publication, 30 July 2004; doi:10.1038/modpathol.3800236

Keywords: chromophobe renal cell carcinoma; renal cell carcinoma; immunohistochemistry; CD10; parvalbumin

The importance of distinguishing the different types of renal cell carcinoma is underscored by the fact that they have different prognoses. ${ }^{1-3}$ CD10, a cell surface metalloproteinase localized to the proximal nephron of the normal adult kidney, ${ }^{4}$ has been proposed as a useful tool in the differential diagnosis of renal epithelial neoplasms. ${ }^{5-7}$ This molecule has been described as a positive immunohistochemical marker for the two most common types of kidney cancer, clear cell and papillary renal cell carcinomas. ${ }^{5-9}$ Previous studies analyzing CD10

Correspondence: Dr G Martignoni, MD, Anatomia Patologica, Università di Sassari, Via G Matteotti 58, 07100, Sassari, Italy.

E-mail: guidomart@yahoo.com

Presented in part at the 19th European Congress of Pathology, Ljubljana, September 6-11, 2003.

Received 2 April 2004; revised and accepted 10 June 2004; published online 30 July 2004 immunoreactivity in a total of 25 chromophobe renal cell carcinomas have found negative reactions, ${ }^{5,7}$ whereas Holm-Nielsen et $a l^{10}$ found CD10 expressed in all three chromophobe carcinomas studied and Higgins et $a l^{11}$ found a positive reaction in one of three tumors tested. In this study we undertook to investigate CD10 and parvalbumin immunoreactivity in a large series of clear cell, papillary, and chromophobe renal cell carcinomas.

\section{Materials and methods}

Patients and Tissue Samples

We studied the immunohistochemical expression of CD10 and parvalbumin in 75 clear cell renal cell carcinomas, 51 papillary renal cell carcinomas and 38 chromophobe renal cell carcinomas (including 36 
of the classic type and two eosinophilic variants), retrieved from the files of the Renal Tumor Registry of the Department of Pathology of the University of Verona, Verona, Italy. These included eight metastases of clear cell renal cell carcinoma (three adrenal, one pulmonary, one hepatic and four pancreatic), two lymph nodal metastases of papillary renal cell carcinoma and one pancreatic metastasis of chromophobe renal cell carcinoma.

CD10 expression was considered negative in cases with completely absent immunohistochemical reactions or with a few scattered positive neoplastic cells.

After we found expression of CD10 in a subset of chromophobe renal cell carcinomas, including cases with aggressive features (pT3a and pT3b and pancreatic metastasis), we added four cases of chromophobe renal cell carcinoma, two with lymph nodal and pulmonary metastases and two with sarcomatoid transformation, coming from the Departments of Pathology of Innsbruck University, Austria, Indiana University, Indianapolis, IN, USA, Istituto Europeo di Oncologia, Milano, Italy, and Hôpital Européen George Pompidou, Paris, France, to further attempt to correlate CD10 expression with clinicopathologic parameters.

We evaluated the following clinicopathologic parameters: sex, age, type of surgery and follow-up data; size, laterality and involvement of perinephric adipose tissue; Hale's colloidal iron stain (a diagnostic hallmark of chromophobe renal cell carcinoma), Fuhrman's grade, mitotic activity (mitotic figures per 50 high power fields), necrosis, vascular invasion, extrarenal extension, and metastases. The tumors were staged using the AJCC/TNM Staging System 2002 and the histopathological parameters were evaluated on an average of 3.7 tumor sections.

The immunohistochemical expression of CD10 was also evaluated in five fetal kidneys (from 16 to 23 weeks of gestation) and in unaffected samples of the kidneys harboring the tumors.

\section{Immunohistochemical Analysis}

For all tumors, serial $5 \mu \mathrm{m}$ sections were immunostained with antibodies recognizing the following markers: CD10 (anti-CD10, 56C6 Novocastra, Burlingame, CA, USA; dilution, 1:20), and parvalbumin (PA-235, Sigma Chemical Company, St Louis, MO, USA; dilution, 1:500). Immunoreactions were developed using three different nonbiotin, highly sensitive systems (Envision peroxidase detection system, DAKO, Carpinteria, CA, USA; Envision-alkalinephosphatase detection system, DAKO, Carpinteria, CA, USA; polymer-system, Biogenex, San Ramon, CA, USA) preventing possible false-positive staining due to endogenous biotin present in the tissue.

Sections of normal adult and fetal renal parenchyma were immunostained using single and multiple marker procedures. In the latter procedure, the sections were consecutively tested for CD10 and parvalbumin, utilizing double Envision-peroxidase immunostaining, followed by Envision-alkalinephosphatase immunostaining.

\section{Western Blot Analysis}

The samples of two chromophobe renal carcinomas and their normal controls (a chronic lymphocytic leukemia cell line as negative control, and a follicular lymphoma cell line as positive control for CD10) were lysed in a buffer containing $20 \mathrm{mM}$ Tris-HCl, pH 8, $100 \mathrm{mM} \mathrm{NaCl}, 0.5 \%$ Triton X-100, $10 \mathrm{mM} \mathrm{NaF}, 1 \mathrm{mM} \mathrm{Na} \mathrm{VO}_{4}, 200 \mathrm{mM}$ DTT, $1 \mathrm{mM}$ PMSF and a cocktail of protease inhibitors for $1 \mathrm{~h}$ on ice.

After centrifugation at $12000 \mathrm{~g}$ for $10 \mathrm{~min}$, protein extracts were recovered and protein concentration was measured by protein assay (Bio- Rad).

Proteins $(30 \mu \mathrm{g})$ were separated on a $12 \%$ SDSPAGE and transferred into Hybond-P PVDF membranes. Equal loading of samples was checked by staining with Ponceau-S. Membranes were then incubated for $1 \mathrm{~h}$ at room temperature with the blocking reagent: 5\% nonfat dried milk in PBST, washed three times in PBST and than incubated overnight at $4^{\circ} \mathrm{C}$ with mouse monoclonal antibodies: anti-CD10 (56C6 Novocastra) and anti-parvalbumin (PA-235, Sigma Chemical Company) at, respectively, 1:33 and 1:2500 final dilution. After three washes in PBST, membranes were incubated for $1 \mathrm{~h}$ at room temperature with an anti-mouse Ig horseradishperoxidase-coniugated antibody from sheep (NXA 931 Amersham Pharmacia Biotech Europe Freiburg, Germany) at 1:10 000 diluition.

After three washes in PBST membranes were revealed with an enhanced chemiluminescence (ECL) system (Amersham Life Science, Freiburg, Germany).

Full range rainbow (Amersham Life Science, England) was run on each gel as standard molecular-weight marker.

\section{Statistical Analysis}

The Pearson $\chi^{2}$ and the Student's $t$-test analyses were used to compare categorical and continuous variables. We tested the possible association between CD10 expression and the clinicopathologic features including gender, age, tumor size, Fuhrman's grade, necrosis, mitotic figures and clinical aggressiveness, which was defined as pathologically proven locally advanced tumors (pT3a and pT3b), presence of synchronous or metachronous distant metastases, or presence of sarcomatoid transformation. Linear regression was used to perform multivariate analysis, which included only the variables significant at univariate analysis. In all the statistical analyses, a two-sided $P<0.05$ was considered significant. All data were analyzed using the 10.1 
Statistical Package for the Social Sciences (SPSS) software.

\section{Results}

\section{Clinical and Pathologic Findings}

The clinical and pathologic findings of chromophobe carcinomas of our series are summarized in Table 1.
Ages ranged from 28 to 81 years (mean 55 years) The female-to-male ratio was 1.3:1. Nephrectomy was the rule, but in six cases a tumorectomy or polar/wedge resection (one case) had been performed. A nephrectomy and a controlateral tumorectomy were performed in a patient affected by bilateral tumors.

Tumors ranged from 25 to $170 \mathrm{~mm}$ in diameter (mean $70 \mathrm{~mm}$ ). A total of 23 tumors affected the left kidney and 19 the right kidney. TNM stages (2002) were: T1a in seven cases, T1b in 14 cases, T2 in 17

Table 1 Clinical, macroscopic, histopathological and immunohistochemical findings of 42 cases of chromophobe renal cell carcinomas

\begin{tabular}{|c|c|c|c|c|c|c|c|c|c|c|}
\hline \multirow{2}{*}{$\begin{array}{l}\text { Case } \\
\text { no. }\end{array}$} & \multirow{2}{*}{$\begin{array}{l}\text { Sex/age } \\
\text { (years) }\end{array}$} & \multirow{2}{*}{$\begin{array}{l}\text { Surgical } \\
\text { treatment }\end{array}$} & \multirow{2}{*}{$\begin{array}{c}\text { Maximun } \\
\text { diameter } \\
(\mathrm{mm})\end{array}$} & \multirow[t]{2}{*}{$T$} & \multirow[t]{2}{*}{$G$} & \multirow[t]{2}{*}{ Necrosis } & \multirow[t]{2}{*}{ Mitosis } & \multirow{2}{*}{$\begin{array}{l}\text { Follow-up } \\
\text { (months) }\end{array}$} & \multicolumn{2}{|c|}{ Immunostain } \\
\hline & & & & & & & & & Parvalbumin & $C D 10$ \\
\hline 1 & $\mathrm{~F} / 71$ & $\mathrm{~N}$ & 120 & $\mathrm{~T} 2$ & 2 & Yes & No & n.a. & $40 \%$ & Negative \\
\hline 2 & $\mathrm{M} / 67$ & $\mathrm{~T}$ & 30 & T1a & 2 & No & $25 / 50 \mathrm{HPF}$ & 165 a\&w & $70 \%$ & Negative \\
\hline 3 & $\mathrm{~F} / 53$ & $\mathrm{~N}$ & 70 & $\mathrm{~T} 2$ & 2 & No & $3 / 50 \mathrm{HPF}$ & $180 \mathrm{a} \& \mathrm{w}$ & $70 \%$ & Negative \\
\hline 4 & $\mathrm{M} / 58$ & $\mathrm{~N}$ & 130 & $\mathrm{~T} 2$ & 2 & No & $3 / 50 \mathrm{HPF}$ & $140 \mathrm{a} \& \mathrm{w}$ & $90 \%$ & Negative \\
\hline 5 & $\mathrm{M} / 76$ & $\mathrm{~N}$ & 80 & $\mathrm{~T} 2$ & 2 & Yes & No & $140 \mathrm{a} \& \mathrm{w}$ & $90 \%$ & Negative \\
\hline 6 & $\mathrm{M} / 67$ & $\mathrm{~T}$ & 25 & T1a & 2 & No & No & $140 \mathrm{a} \& w$ & $40 \%$ & Negative \\
\hline 7 & $\mathrm{~F} / 37$ & $\mathrm{~N}$ & 110 & $\mathrm{~T} 2$ & 3 & No & No & $120 \mathrm{a} \& \mathrm{w}$ & $90 \%$ & Negative \\
\hline 8 & $\mathrm{M} / 54$ & $\mathrm{~N}$ & 34 & T1a & 2 & No & $2 / 50 \mathrm{HPF}$ & $120 \mathrm{a} \& \mathrm{w}$ & $50 \%$ & Negative \\
\hline 9 & $\mathrm{M} / 60$ & $\mathrm{~N}$ & 90 & $\mathrm{~T} 2$ & 2 & No & $3 / 50 \mathrm{HPF}$ & 125 a\&w & $80 \%$ & Negative \\
\hline 10 & $\mathrm{~F} / 28$ & $\mathrm{~N}$ & 25 & T1a & 2 & No & $3 / 50 \mathrm{HPF}$ & $100 \mathrm{a} \& \mathrm{w}$ & $80 \%$ & Negative \\
\hline 11 & $F / 64$ & $\mathrm{~N}$ & 110 & $\mathrm{~T} 2$ & 3 & Yes & 12/50HPF & $80 \mathrm{a} \& \mathrm{w}$ & $80 \%$ & Negative \\
\hline 12 & $\mathrm{~F} / 42$ & $\mathrm{~N}$ & 40 & $\mathrm{~T} 1 \mathrm{~b}$ & 3 & Yes & 19/50HPF & $60 \mathrm{a} \& \mathrm{w}$ & $70 \%$ & Negative \\
\hline 13 & $\mathrm{~F} / 73$ & $\mathrm{~T}$ & 40 & $\mathrm{~T} 1 \mathrm{~b}$ & 3 & No & $2 / 50 \mathrm{HPF}$ & $35 \mathrm{a} \& \mathrm{w}$ & $80 \%$ & Negative \\
\hline 14 & $\mathrm{~F} / 35$ & $\mathrm{~T}$ & 40 & $\mathrm{~T} 1 \mathrm{~b}$ & 3 & No & No & $35 \mathrm{a} \& w$ & $90 \%$ & Negative \\
\hline 15 & $\mathrm{~F} / 62$ & $\mathrm{~N}$ & 40 & $\mathrm{~T} 1 \mathrm{~b}$ & 2 & No & No & $38 \mathrm{a} \& \mathrm{w}$ & $90 \%$ & Negative \\
\hline 16 & $\mathrm{~F} / 81$ & $\mathrm{~N}$ & 40 & $\mathrm{~T} 1 \mathrm{~b}$ & 2 & No & 4/50HPF & n.a. & $60 \%$ & Negative \\
\hline 17 & $\mathrm{~F} / 63$ & $\mathrm{~N}$ & 90 & $\mathrm{~T} 2$ & 2 & No & $3 / 50 \mathrm{HPF}$ & n.a. & $70 \%$ & Negative \\
\hline 18 & $\mathrm{~F} / 46$ & $\mathrm{~N}$ & 75 & $\mathrm{~T} 2$ & 2 & No & No & n.a. & $70 \%$ & Negative \\
\hline 19 & $\mathrm{~F} / 42$ & $\mathrm{~N}$ & 80 & $\mathrm{~T} 2$ & 3 & No & 2/50HPF & n.a. & $80 \%$ & Negative \\
\hline 20 & $\mathrm{~F} / 74$ & $\mathrm{~N}$ & 45 & $\mathrm{~T} 1 \mathrm{~b}$ & 2 & Yes & $4 / 50 \mathrm{HPF}$ & n.a. & $80 \%$ & Negative \\
\hline 21 & $\mathrm{M} / 54$ & $\mathrm{~N}$ & 40 & $\mathrm{~T} 1 \mathrm{~b}$ & 3 & No & No & n.a. & $80 \%$ & Negative \\
\hline 22 & $\mathrm{M} / 64$ & $\mathrm{~N}$ & 50 & $\mathrm{~T} 1 \mathrm{~b}$ & 2 & No & $2 / 50 \mathrm{HPF}$ & n.a. & $90 \%$ & Negative \\
\hline 23 & $\mathrm{M} / 30$ & $\mathrm{~N}$ & 100 & $\mathrm{~T} 2$ & 3 & No & No & $32 \mathrm{a} \& \mathrm{w}$ & $70 \%$ & Negative \\
\hline 24 & $\mathrm{~F} / 43$ & P. RES. & 30 & T1a & 2 & Yes & 9/50HPF & $72 \mathrm{a} \& w$ & $80 \%$ & Negative \\
\hline 25 & $\mathrm{~F} / 34$ & $\mathrm{~N}$ & 100 & $\mathrm{~T} 2$ & 2 & No & $5 / 50 \mathrm{HPF}$ & $60 \mathrm{a} \& \mathrm{w}$ & $70 \%$ & Negative \\
\hline 26 & $\mathrm{M} / 58$ & $\mathrm{~N}$ & 50 & $\mathrm{~T} 1 \mathrm{~b}$ & 3 & No & $2 / 50 \mathrm{HPF}$ & $70 \mathrm{a} \& w$ & $80 \%$ & Negative \\
\hline 27 & $\mathrm{M} / 75$ & $\mathrm{~N}$ & 75 & $\mathrm{~T} 2$ & 3 & Yes & No & n.a. & $70 \%$ & Negative \\
\hline 28 & M/66 & $\mathrm{T}$ & 25 & T1a & 2 & No & No & n.a. & $80 \%$ & Negative \\
\hline 29 & $\mathrm{M} / 67$ & $\mathrm{~N}$ & 35 & T1a & 2 & No & No & n.a. & $70 \%$ & Negative \\
\hline 30 & n.a. & $\mathrm{N}$ & n.a. & n.a. & 3 & Yes & 8/50HPF & n.a. & $80 \%$ & Negative \\
\hline $31 a$ & $\mathrm{~F} / 53$ & $\mathrm{~N}$ & 100 & $\mathrm{~T} 2$ & 2 & Yes & No & n.a. & $90 \%$ & Negative \\
\hline $31 \mathrm{~b}$ & $\mathrm{~F} / 63$ & $\begin{array}{l}\text { Pulmonary } \\
\text { metastasis }\end{array}$ & & M1 & & Yes & No & 120 alive & $90 \%$ & Negative \\
\hline $32 \mathrm{a}$ & $\mathrm{M} / 43$ & $\mathrm{~N}$ & 90 & $\mathrm{~T} 2$ & 2 & Yes & $32 / 50 \mathrm{HPF}$ & n.a. & $90 \%$ & $80 \%$ \\
\hline $32 b$ & $\mathrm{M} / 55$ & $\begin{array}{l}\text { Pancreatic } \\
\text { metastasis }\end{array}$ & & M1 & & Yes & 18/50HPF & 144 alive & $80 \%$ & $80 \%$ \\
\hline 33 & $\mathrm{M} / 61$ & $\mathrm{~N}$ & 170 & $\mathrm{~T} 2$ & 2 & Yes & 8/50HPF & $180 \mathrm{a} \& \mathrm{w}$ & $90 \%$ & $70 \%$ \\
\hline 34 & $\mathrm{M} / 46$ & $\mathrm{~N}$ & 65 & $\mathrm{~T} 1 \mathrm{~b}$ & 3 & No & $1 / 50 \mathrm{HPF}$ & $110 \mathrm{a} \& \mathrm{w}$ & $80 \%$ & $50 \%$ \\
\hline 35 & M/66 & $\mathrm{N}$ & 150 & $\mathrm{~T} 3 \mathrm{~b}$ & 3 & Yes & $2 / 50 \mathrm{HPF}$ & $40 \mathrm{a} \& \mathrm{w}$ & $90 \%$ & $90 \%$ \\
\hline 36 & $\mathrm{~F} / 51$ & $\mathrm{~N}$ & 40 & $\mathrm{~T} 1 \mathrm{~b}$ & 2 & No & $1 / 50 \mathrm{HPF}$ & $180 \mathrm{a} \& \mathrm{w}$ & $70 \%$ & $80 \%$ \\
\hline 37 & $\mathrm{~F} / 48$ & $\mathrm{~N}$ & 70 & $\mathrm{~T} 2$ & 3 & No & 7/50HPF & n.a. & $90 \%$ & $70 \%$ \\
\hline 38 & $\mathrm{~F} / 59$ & $\mathrm{~N}$ & 40 & $\mathrm{~T} 1 \mathrm{~b}$ & 3 & No & $1 / 50 \mathrm{HPF}$ & n.a. & $80 \%$ & $30 \%$ \\
\hline 39 & $\mathrm{M} / 39$ & $\mathrm{~N}$ & 140 & Т3а & 3 & Yes & No & n.a. & $70 \%$ & $50 \%$ \\
\hline 40 & $\mathrm{M} / 45$ & $\mathrm{~N}$ & 50 & $\mathrm{~T} 1 \mathrm{~b}$ & 2 & No & 4/50HPF & n.a. & $70 \%$ & $90 \%$ \\
\hline 41a & $\mathrm{M} / 66$ & $\mathrm{~N}$ & 64 & $\mathrm{~T} 1 \mathrm{~b}$ & 3 & Yes & $3 / 50 \mathrm{HPF}$ & n.a. & $70 \%$ & $60 \%$ \\
\hline $41 \mathrm{~b}$ & $\mathrm{M} / 71$ & $\begin{array}{l}\text { Lymph nodal } \\
\text { metastasis }\end{array}$ & & N1 & & Yes & 2/50HPF & 60 alive & $80 \%$ & $90 \%$ \\
\hline 42 & n.a. & $\mathrm{N}$ & n.a. & n.a. & 3 & Yes & 18/50HPF & n.a. & $80 \%$ & $70 \%$ \\
\hline
\end{tabular}

N, nephrectomy; T, tumorectomy; P. RES., polar resection; T, local invasiveness; HPF, high power field; \%, percentage of positive neoplastic cells; n.a.: not available; a\&w, alive and well; alive, alive without evidence of disease. 
cases, T3a and T3b in one case, respectively, at the time of the nephrectomy or tumorectomy.

Morphologically, nuclei of the neoplastic cells were grade 2 in 25 tumors and grade 3 in 17 (Figure 1a). No mitotic figures could be found in 14 tumors, whereas in 9 primary neoplasms there were more than 5 mitotic figures per 50 high-power fields
(Figure 1b). Necrosis was seen in 15 primary tumors, including both gross (10 cases) and microscopic (five cases) foci. Involvement of the renal vein and perinephric fat invasion were observed in one case each.

Retroperitoneal lymph nodal (Figure 1c), pulmonary (Figure 1d) and pancreatic (Figure 1e) metachronous metastases of chromophobe carcinoma were
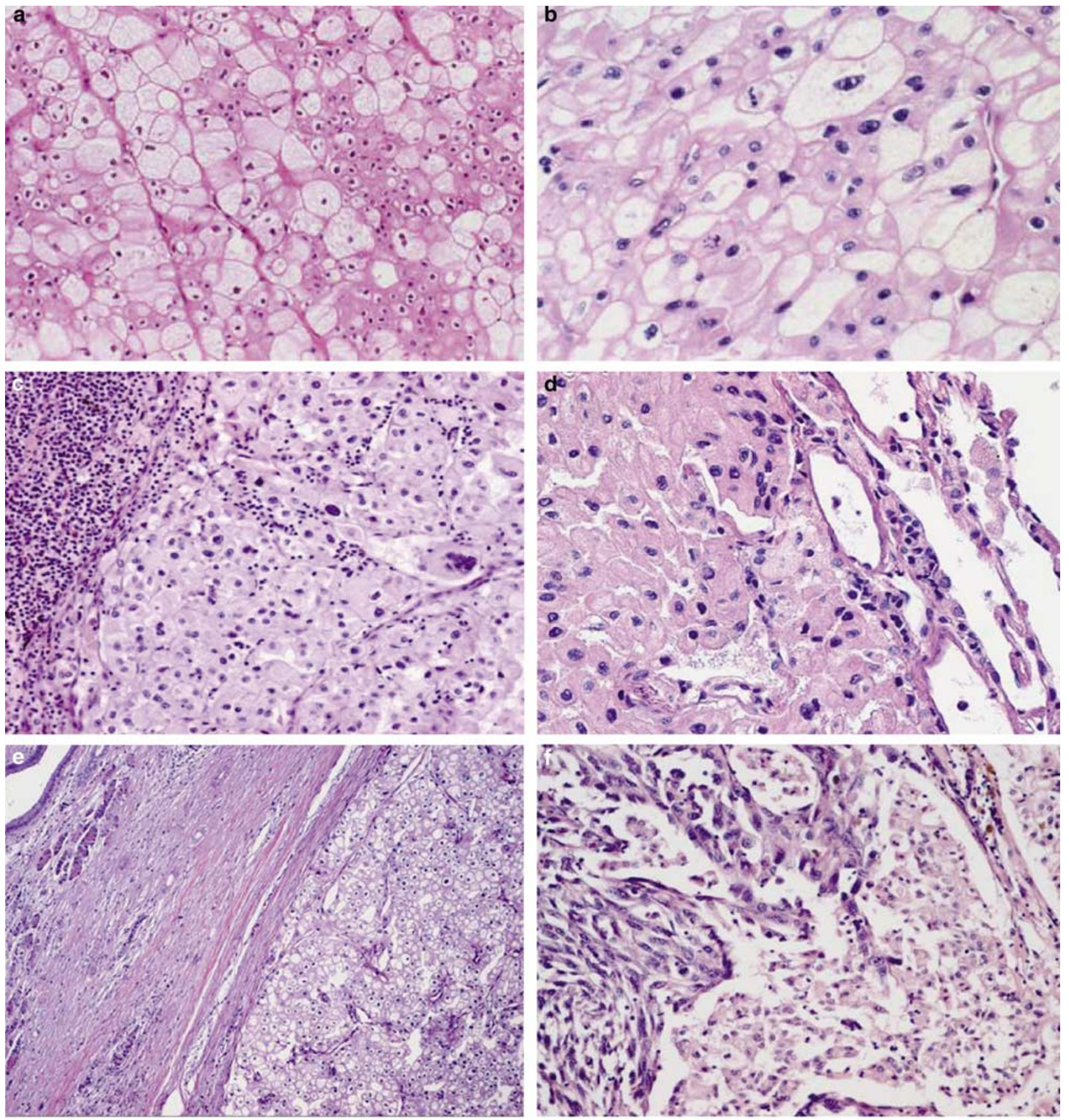

Figure 1 (a) Chromophobe renal cell carcinoma (hematoxylin and eosin, $\times 20$ ). (b) Chromophobe renal cell carcinoma with focus on two mitotic figures (arrows) (hematoxylin and eosin, $\times 40)$. (c) Metastasis of chromophobe renal cell carcinoma to retroperitoneal lymph node (hematoxylin and eosin, $\times 20$ ). (d) Pulmonary metastasis of chromophobe renal cell carcinoma (hematoxylin and eosin, $\times 40)$. (e) Pancreatic metastasis of chromophobe renal cell carcinoma (hematoxylin and eosin stain, $\times 10$ ). (f) Chromophobe renal cell carcinoma with sarcomatoid transformation (hematoxylin and eosin, $\times 20$ ). 
found 5, 10 and 12 years after surgery, respectively. Sarcomatoid changes were present in two cases (Figure 1f). A median follow-up of 103 months (8.6 years) was available for 25 patients. No follow-up information was available regarding the two cases with sarcomatoid changes. All patients with followup data are alive, including those with metastatic disease. The patient with the bilateral tumors displayed a classic chromophobe renal cell carcinoma (nephrectomy) and a synchronous contralateral clear cell renal cell carcinoma $(50 \mathrm{~mm}$ in diameter, nuclear grade 2, treated with tumorectomy).

\section{Histochemical Findings}

All but one chromophobe renal cell carcinomas stained with Hale's colloidal iron histochemical method.
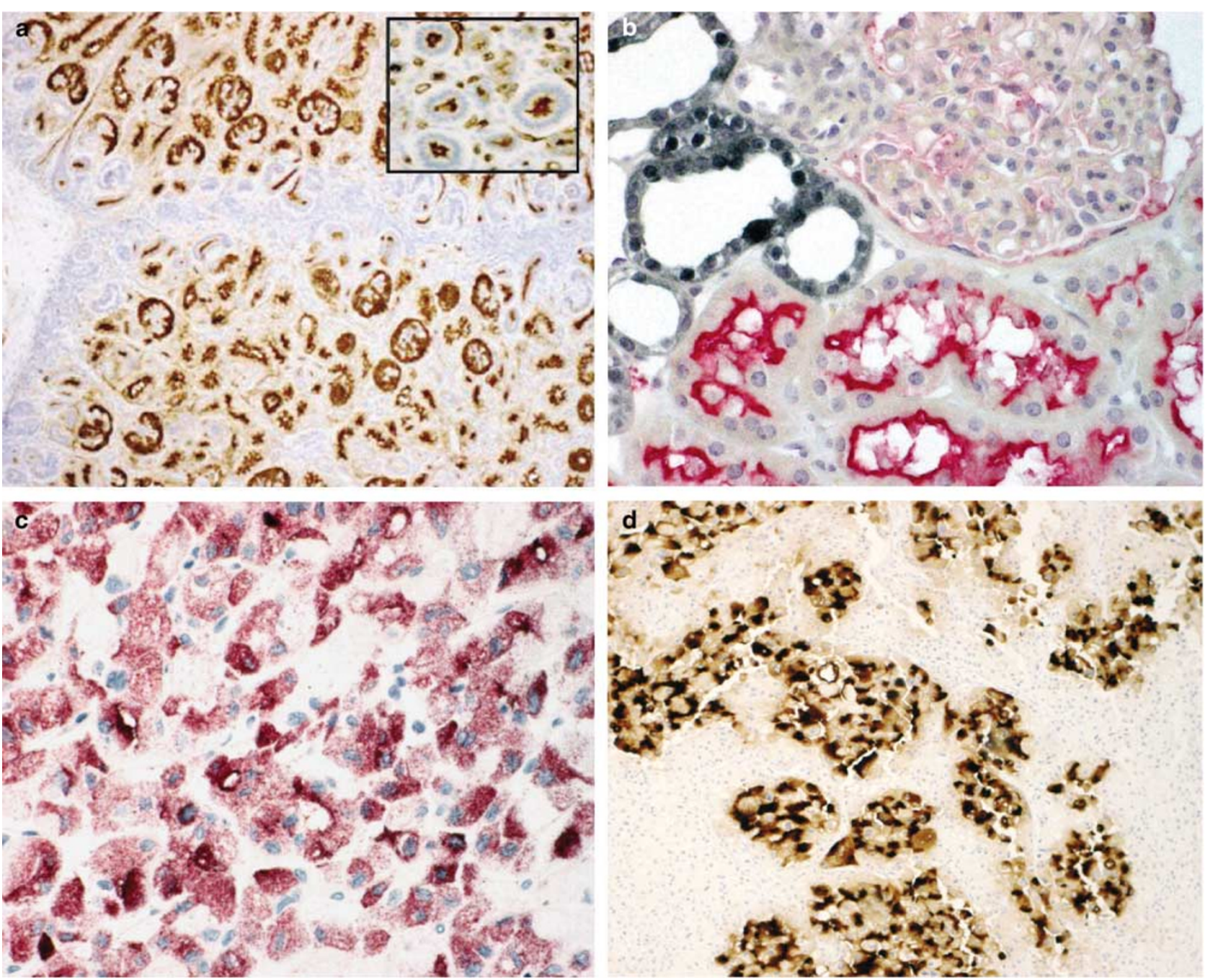

Figure 2 (a) CD10 immunostain (Envision peroxidase detection system, DAKO) in fetal kidney (23th week): CD10 was extensively expressed in the podocytes of the glomeruli, in Bowman's capsule, in the epithelial cells of the proximal tubules, and in the collecting duct cells of the medullary region (frame). CD10 immunostain was not expressed in the renal structures of the nephrogenic zone, as well as in the midplane of the cortical columns of Bertini, the zone of contact between adjacent lobes. (b) Section of normal adult renal parenchyma consecutively immunostained for CD10 (Envision alkaline-phosphatase detection system, DAKO) and parvalbumin (Envision peroxidase detection system, DAKO). CD10 stained the glomerular epithelium, Bowman's capsule and the normal proximal tubular cells, which showed strong surface membrane staining. Parvalbumin was constantly and strongly expressed, with a cytoplasmic and nuclear pattern, in a variable number of cells of distal convoluted tubules, connecting tubule, and in a subset of collecting duct cells, likely intercalated cells. (c) A case of CD10-positive chromophobe renal cell carcinoma: the neoplastic cells displayed a strong, cytoplasmic granular staining with a surface immunoreactivity highlighting microlumina (Envision alkaline-phosphatase detection system, DAKO). (d) CD10 immunostain in a case of chromophobe renal cell carcinoma (Envision peroxidase detection system, DAKO) underlining the patchy staining pattern. (e) CD10 immunostain in the retroperitoneal lymph nodal metastasis of chromophobe renal cell carcinoma (Envision peroxidase detection system, DAKO). (f) Parvalbumin immunostain in the retroperitoneal lymph nodal metastasis of chromophobe renal cell carcinoma (Envision peroxidase detection system, DAKO). (g) Parvalbumin immunostain in the pulmonary metastasis of chromophobe renal cell carcinoma (Envision peroxidase detection system, DAKO). (h) Parvalbumin immunostain in a case of chromophobe renal cell carcinoma with sarcomatoid transformation: positive stain in the epithelial component and negative in the sarcomatoid area (Envision peroxidase detection system, DAKO). 


\section{Immunohistochemical Findings}

Fetal and normal adult kidney

In fetal kidney, CD10 was extensively expressed in podocytes within the glomeruli, in the Bowman's capsule, in the epithelial cells of the proximal tubules and collecting duct cells of the medullary region. CD10 immunostain was absent in the renal structures of the nephrogenic zone, which is present at the capsular surface of the kidney as well as in the midplane of the cortical columns of Bertin, the zone of contact between adjacent lobes (Figure 2a).

In normal adult kidney, CD10 stained the glomerular epithelium, Bowman's capsule and the normal proximal tubular cells, which showed a strong surface membrane staining (Figure 2b).

Parvalbumin was constantly and strongly expressed, with a cytoplasmic and nuclear pattern, in a variable number of cells of distal convoluted tubules, connecting tubules, and in a subset of collecting duct cells, likely intercalated cells (Figure 2b).

\section{Renal tumors}

The results describing the immunoreactivity of CD10 and parvalbumin on the chromophobe renal cell carcinomas are summarized in Table 1.

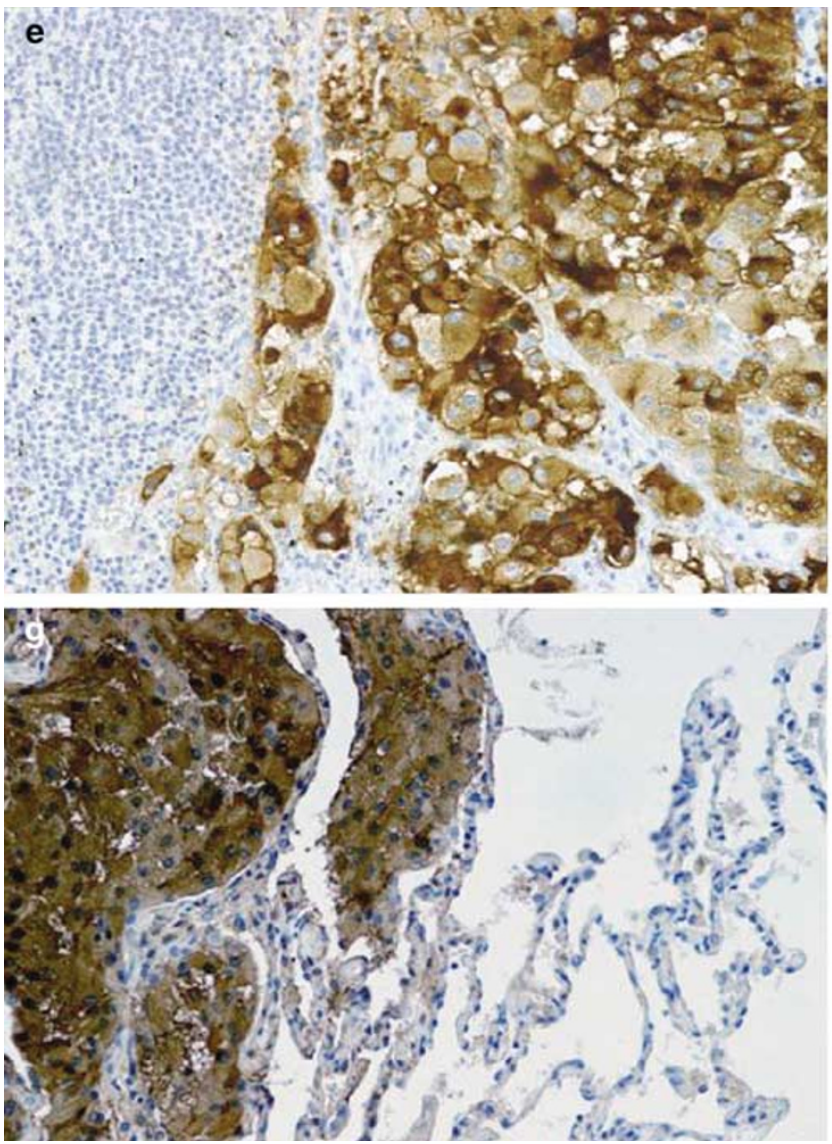

Of 42 primary chromophobe renal cell carcinomas, $11(26 \%)$ were immunoreactive for CD10. These included five $(71 \%)$ of the seven cases with aggressive features, whereas only three (9\%) of the 35 without aggressive features. In the positive tumors, the neoplastic cells displayed a strong, cytoplasmic granular staining, with an immunoreactivity highlighting intercellular and intracellular microlumina (Figure 2c). No significant differences in the immunoreactivity of the three different cell types described by Akhtar et $a l^{12}$ in chromophobe renal cell carcinoma were observed. The percentage of CD10 positive tumor cells varied from 30 to $90 \%$ in different tumors, with an alternation between positive and negative areas (Figure $2 \mathrm{~d}$ ).

Two of the three cases with distant metastases were CD10 immunoreactive (Figure 2e). The CD10 reactivity was always concordant in the primary and metastatic tumors. One of the two chromophobe renal cell carcinomas with areas of sarcomatoid transformation was CD10-positive both in the residual chromophobe cell component and in the spindle cell component.

All 75 of the clear cell renal cell carcinomas and 32 of $51(63 \%)$ papillary renal cell carcinomas showed membranous immunostaining for CD10. The metastases of both types were also positive.

Figure 2 Continued.

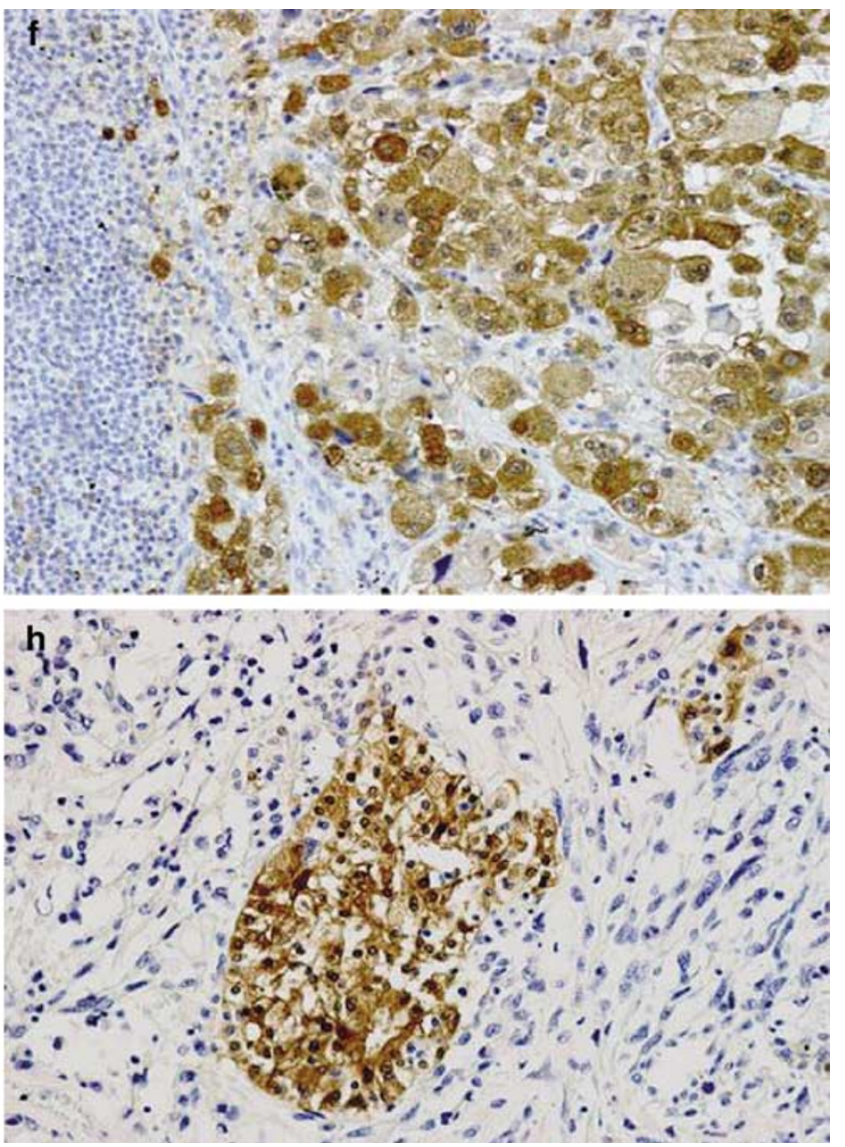


All chromophobe renal cell carcinomas, including the metastases (Figure 2f,g), showed a strong cytoplasmic and nuclear immunoreactivity for parvalbumin. Sarcomatoid areas, when present, were negative (Figure 2h). All of the clear cell and papillary renal cell carcinomas did not express significant levels of parvalbumin.

\section{Western Blot Findings}

The specificity of immunodetection of both CD10 and parvalbumin was confirmed by Western blot analysis in two samples of chromophobe renal cell carcinomas (Figure 3). The Western blots showed bands consistent with the $100 \mathrm{kDa}$ CD10 protein in the CD10-positive samples (chromophobe renal cell carcinoma, normal renal parenchyma and a follicular lymphoma cell line used as control). The band was not found with CD10-negative tumors. The analysis for anti-parvalbumin displayed a band consistent with the $12 \mathrm{kDa}$ parvalbumin protein in a chromophobe renal cell carcinoma and in normal renal parenchyma, but not in the control.

\section{Statistical Findings}

The statistical findings are summarized in Tables 2 and 3. The statistical analysis of the data showed significant association of CD10-positive chromophobe renal cell carcinomas with clinical aggressiveness $(P=0.003)$, as previously defined, and with the presence of mitotic figures $(P=0.04)$. At univariate analysis, only the presence of necrosis $(P<0.001)$ and CD10 expression $(P=0.003)$ were significant. Both of them were independent predictive variables in multivariate analysis (Table 3 ).

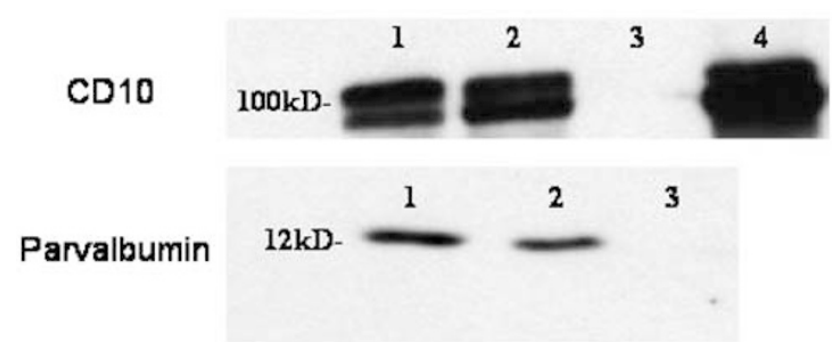

Figure 3 Western blot for anti-CD10 showing bands corresponding in size to the $100 \mathrm{kDa}$ protein in one case of chromophobe renal cell carcinoma and in the positive control (follicular lymphoma cell line), but not in the negative control (chronic lymphocytic leukemia). Lane 1: chromophobe renal cell carcinoma; lane 2: normal kidney adjacent to chromophobe renal cell carcinoma; lane 3: chronic lymphocytic leukemia cell line; lane 4: follicular lymphoma cell line. Western blot for antiparvalbumin showing bands corresponding in size to the $12 \mathrm{kDa}$ protein in a case of chromophobe renal cell carcinoma but not in the negative control (chronic lymphocytic leukemia cell line). Lane 1: chromophobe renal cell carcinoma; lane 2: normal kidney adjacent to chromophobe renal cell carcinoma; lane 3: chronic lymphocytic leukemia.
Table 2 Correlation between clinical and pathological variables with CD10 analysis

\begin{tabular}{|c|c|c|c|}
\hline Variables & $\begin{array}{c}\text { CD } 10 \\
\text { negative } \\
\text { (31 cases) }\end{array}$ & $\begin{array}{c}\text { CD 10 } \\
\text { positive } \\
(11 \text { cases })\end{array}$ & $\begin{array}{l}\text { P-value } \\
(<0.05)\end{array}$ \\
\hline Gender & & & 0.11 \\
\hline Male & $14(64 \%)$ & $8(36 \%)$ & \\
\hline Female & $17(85 \%)$ & $3(15 \%)$ & \\
\hline Age (years, mean \pm s.d.) & $57 \pm 15$ & $53 \pm 10$ & 0.43 \\
\hline Size (mm, mean \pm s.d.) & $65 \pm 33$ & $89 \pm 50$ & 0.1 \\
\hline Fuhrman grading & & & 0.1 \\
\hline Grade 2 & $20(83 \%)$ & $4(17 \%)$ & \\
\hline Grade 3 & $11(61 \%)$ & $7(39 \%)$ & \\
\hline Necrosis & & & 0.12 \\
\hline Absent & $22(71 \%)$ & $5(19 \%)$ & \\
\hline Present & $9(29 \%)$ & $6(40 \%)$ & \\
\hline Mitosis & & & 0.04 \\
\hline Absent & $13(93 \%)$ & $1(7 \%)$ & \\
\hline Present & $18(64 \%)$ & $10(36 \%)$ & \\
\hline Clinical aggressiveness ${ }^{\mathrm{a}}$ & & & 0.003 \\
\hline Absent & $29(83 \%)$ & $6(17 \%)$ & \\
\hline Present & $2(29 \%)$ & $5(71 \%)$ & \\
\hline
\end{tabular}

${ }^{\mathrm{a} O n e}$ patient pT3a-one patient pT3b-one patient with synchronous metastasis-two patients with metachronous metastasis-two patients with carcinoma with sarcomatoid transformation.

Table 3 Clinical aggressiveness: univariate and multivariate analyses $(P<0.05)$

\begin{tabular}{lcc}
\hline Variable & Univariate analysis & Multivariate analysis \\
\hline Gender & 0.053 & n.a. \\
Age & 0.956 & n.a. \\
Size & 0.056 & n.a. \\
Fuhrman grading & 0.094 & n.a. \\
Necrosis & 0.001 & 0.001 \\
Mitosis & 0.77 & n.a. \\
CD10 & 0.003 & 0.002 \\
\hline
\end{tabular}

n.a., not applicable.

\section{Discussion}

In this study, we detected the expression of CD10 in $26 \%$ of chromophobe renal cell carcinomas. This is significant because it shows that CD10 is not a specific marker for clear cell and papillary renal cell carcinomas as has been asserted in previous reports. However, by including parvalbumin in the immunohistochemical panel for the differential diagnosis of primary and metastatic renal cell carcinomas, diagnostic specificity can be improved, especially in assessing metastases where oncocytoma is not a consideration. Parvalbumin is a calcium-binding protein proposed recently as a useful marker to identify renal epithelial neoplasms with differentiation toward the distal nephron such as chromophobe renal cell carcinoma and oncocytoma. ${ }^{13-15}$ In this study, we demonstrated that parvalbumin immunostained all 42 chromophobe renal cell carcinoma and used Western blot analysis to 
confirm the presence of parvalbumin in the neoplastic cells. In our study, we found that all metastatic clear cell and papillary renal cell carcinomas and two of the three metastatic chromophobe renal cell carcinomas were positive for CD10. Immunohistochemistry for parvalbumin would clarify this differential diagnosis since it is consistently positive in chromophobe renal cell carcinoma and negative in clear cell and papillary renal cell carcinomas. The same approach can be used with primary tumors if oncocytoma is not a consideration.

Endogenous biotin in kidney tissue and renal tumors can lead to confusing results. In this study, three different developing systems that are not sensitive to endogenous biotin were used to overcome this problem. The results were identical with each of the developing systems. Using these systems, clear cell renal cell carcinoma appears to be consistently negative for parvalbumin. This difference in methodology may account for differences between the results of this study and the results of previous studies that used methods sensitive to endogenous biotin.

CD10 immunoreactivity was observed in the collecting duct cells of the fetal kidney between the 16th and 23rd weeks of gestation. This correlates with the observation of CD10 expression in chromophobe renal cell carcinomas, since these tumors exhibit other forms of differentiation toward the collecting duct phenotype. ${ }^{13,16}$ The presence of markers of different segments of the nephron may reflect abnormal gene expression associated with the neoplastic changes of chromophobe renal cell carcinoma. Our investigation of fetal kidney has shown that CD10 expression is present in epithelial cells of both the proximal and distal nephron.

This study also found a statistically significant relationship between CD10 expression and clinicopathologic aggressiveness in chromophobe renal cell carcinomas $(P=0.003)$. CD10 expression was also correlated with the presence of mitotic figures $(P=0.04)$. The measures of clinicopathologic aggressiveness included renal vein involvement, perinephric fat invasion and distant metastases, all of which are quite uncommon in chromophobe renal cell carcinomas. ${ }^{17,18}$ This suggests that detection of CD10 in a chromophobe renal cell carcinoma may indicate the potential for more aggressive behavior than is expected in other chromophobe renal cell carcinomas. Moreover, among the traditional pathological parameters, only the presence of necrosis predicted clinical aggressiveness in this set of chromophobe renal cell carcinomas. Multivariate analysis showed independent predictive roles for both CD10 expression and presence of necrosis.

Most renal epithelial neoplasms can be diagnosed reliably by experienced pathologists on the basis of hematoxylin and eosin morphology alone, but numerous difficult cases exist. Data about the expression profiling of renal epithelial neoplasms have been growing in the recent literature $\mathrm{e}^{15,19-22}$ and the search for immunohistochemical markers uniquely positive for the most common renal cell neoplasms is extensive. ${ }^{5,13,15,22-25}$

CD10 has been suggested as a marker useful in the differential diagnosis of renal tumors. ${ }^{5-8}$ Droz et $a l^{8}$ observed CD10 immunoreactivity in all 28 renal cell carcinomas tested and Chu and Arber ${ }^{6}$ reported 41 out of 46 renal cell carcinomas (clear cell and papillary renal cell carcinomas) positive for CD10, but no chromophobe renal cell carcinomas were evaluated in these studies. Avery et $a l^{5}$ found CD10 in 58 of $62(94 \%)$ clear cell and 13 of $14(93 \%)$ papillary renal cell carcinomas, whereas all 19 chromophobe renal cell carcinomas were considered negative in that study. $\mathrm{Kim}$ and $\mathrm{Kim}^{7}$ also reported most clear cell and papillary renal cell carcinomas as positive for CD10, but found chromophobe renal cell carcinoma to be negative for this marker.

At variance with these studies, we found that 11 of $42(26 \%)$ chromophobe renal cell carcinomas were immunoreactive for CD10. The neoplastic cells displayed a strong cytoplasmic granular staining, with an immunoreactivity highlighting intercellular and intracellular lumens, this latter corresponding to the intracytoplasmic lumens described in chromophobe renal cell carcinoma by Krishnan and Truong. ${ }^{26}$ We confirmed the presence of the CD10 protein in the neoplastic cells by Western blot analysis. The population of CD10-positive neoplastic cells ranged from 30 to $90 \%$ of the entire population with an alternation between positive and negative areas in the same tumor that could cause negative results if CD10 immunohistochemistry is used in tissue microarray analysis.

\section{Acknowledgements}

This work was supported in part by Fondazione Cassa di Risparmio di Verona (bando 2001), Banco di Sardegna (2003), AIRC, Milan, MIUR, Diagnostica Molecolare in Oncologia (2003). We thank Dr Aldo Scarpa and Dr Giuseppe Zamboni for helpful discussions and Mihaela Mina, Licia Montagna, Paola Piccoli, and Serena Pedron for their technical assistance.

\section{References}

1 Moch H, Gasser T, Amin MB, et al. Prognostic utility of the recently recommended histologic classification and revised TNM staging system of renal cell carcinoma: a Swiss experience with 588 tumors. Cancer 2000;89:604-614.

2 Amin MB, Amin MB, Tamboli $\mathrm{P}$, et al. Prognostic impact of histologic subtyping of adult renal epithelial neoplasms: an experience of 405 cases. Am J Surg Pathol 2002;26:281-291. 
3 Cheville JC, Lohse CM, Zincke H, et al. Comparisons of outcome and prognostic features among histologic subtypes of renal cell carcinoma. Am J Surg Pathol 2003;27:612-624.

4 McIntosh GG, Lodge AJ, Watson P, et al. NCL-CD10270: a new monoclonal antibody recognizing CD10 in paraffin-embedded tissue. Am J Pathol 1999;154: 77-82.

5 Avery AK, Beckstead J, Renshaw AA, et al. Use of antibodies to RCC and CD10 in the differential diagnosis of renal neoplasms. Am J Surg Pathol 2000; 24:203-210.

6 Chu P, Arber DA. Paraffin-section detection of CD10 in 505 nonhematopoietic neoplasms. Frequent expression in renal cell carcinoma and endometrial stromal sarcoma. Am J Clin Pathol 2000;113: 374-382.

7 Kim MK, Kim S. Immunohistochemical profile of common epithelial neoplasms arising in the kidney. Appl Immunohistochem Mol Morphol 2002;10: 332-338.

8 Droz D, Zachar D, Charbit L, et al. Expression of the human nephron differentiation molecules in renal cell carcinomas. Am J Pathol 1990;137:895-905.

9 Borowitz MJ, Weiss MA, Bossen EH, et al. Characterization of renal neoplasms with monoclonal antibodies to leukocyte differentiation antigens. Cancer 1986;57: 251-256.

10 Holm-Nielsen P, Pallesen G. Expression of segmentspecific antigens in the human nephron and in renal epithelial tumors. APMIS Suppl 1988;4:48-55.

11 Higgins JP, Shinghal R, Gill H, et al. Gene expression patterns in renal cell carcinoma assessed by complementary DNA microarray. Am J Pathol 2003;162: 925-932.

12 Akhtar M, Kardar H, Linjawi T, et al. Chromophobe cell carcinoma of the kidney. A clinicopathologic study of 21 cases. Am J Surg Pathol 1995;19: 1245-1256.

13 Martignoni G, Pea M, Chilosi M, et al. Parvalbumin is constantly expressed in chromophobe renal carcinoma. Mod Pathol 2001;14:760-767.

14 Boer JM, Huber WK, Sultmann H, et al. Identification and classification of differentially expressed genes in renal cell carcinoma by expression profiling on a global human 31,500-element cDNA array. Genome Res 2001;11:1861-1870.
15 Young AN, de Oliveira Salles PG, Lim SD, et al. Beta defensin-1, parvalbumin, and vimentin: a panel of diagnostic immunohistochemical markers for renal tumors derived from gene expression profiling studies using cDNA microarrays. Am J Surg Pathol 2003;27: 199-205.

16 Störkel S, Steart PV, Drenckhahn D, et al. The human chromophobe cell renal carcinoma: its probable relation to intercalated cells of the collecting duct. Virchows Arch B Cell Pathol 1989;56:237-245.

17 Martignoni G, Eble JN, Brunelli M, et al. Chromophobe renal cell carcinoma: a clinicopathologic study of 100 cases. Mod Pathol 2003;16:161A.

18 Störkel S, Martignoni G, van den Berg E. Chromophobe renal cell carcinoma. In: Eble JN, Sauter G, Epstein J, Sesterhenn I (eds). Pathology and Genetics of Tumours of the Urinary System and Male Genital Organs. IARC Press: Lyon, France: 2004, pp 30-32.

19 Moch H, Schraml P, Bubendorf L, et al. Highthroughput tissue microarray analysis to evaluate genes uncovered by cDNA microarray screening in renal cell carcinoma. Am J Pathol 1999;154:981-986.

20 Takahashi M, Rhodes DR, Furge KA, et al. Gene expression profiling of clear cell renal cell carcinoma: gene identification and prognostic classification. Proc Natl Acad Sci 2001;98:9754-9759.

21 Young AN, Amin MB, Moreno CS, et al. Expression profiling of renal epithelial neoplasms: a method for tumor classification and discovery of diagnostic molecular markers. Am J Pathol 2001;158:1639-1651.

22 Li G, Cuilleron M, Gentil-Perret A, et al. Rapid and sensitive detection of messenger RNA expression for molecular differential diagnosis of renal cell carcinoma. Clin Cancer Res 2003;9:6441-6446.

$23 \mathrm{Wu}$ SL, Kothari P, Wheeler TM, et al. Cytokeratins 7 and 20 immunoreactivity in chromophobe renal cell carcinomas and renal oncocytomas. Mod Pathol 2002; 15:712-717.

24 Rampino T, Gregorini M, Soccio G, et al. The Ron proto-oncogene product is a phenotypic marker of renal oncocytoma. Am J Surg Pathol 2003;27:779-785.

25 Tretiakova MS, Sahoo S, Takahashi M, et al. Expression of alpha-methylacyl-coA racemase in papillary renal cell carcinoma. Am J Surg Pathol 2004;28:69-76.

26 Krishnan B, Truong LD. Renal epithelial neoplasms: the diagnostic implications of electron microscopic study in 55 cases. Hum Pathol 2002;33:68-79. 